\title{
First record of Longidorus danuvii Barsi, Lamberti and De Luca, 2007 (Nematoda: Longidoridae) from Poland with description of pathologies of the lip region and reproductive system
}

\author{
F. W. KORNOBIS
}

\author{
Department of Animal Morphology, Faculty of Biology, Adam Mickiewicz University, Umultowska 89, \\ 61-614 Poznań, Poland, E-mail: franciszek.kornobis@amu.edu.pl
}

\begin{abstract}
Summary
Up to date, fourteen species of the genus Longidorus have been recorded from Poland. During a recent survey, $L$. danuvii Barsi, Lamberti and De Luca, 2007 was found for the first time. It is also the first record outside Serbia, from where it was described. Among normal females two pathological specimens were found: one bivulval with abnormal structure of the genital tract and one with deformated lip region. Description of both normal and pathological females is provided. Normal females are similar to populations from Serbia, the main difference is shorter tail in population from Poland (41.6 vs 46.4 and 46.5) and lower c' value (1.60 vs 1.70 and 1.85).
\end{abstract}

Keywords: Longidorus danuvii; Poland; bivulval female

\section{Introduction}

Up to date, fourteen species of the genus Longidorus have been recorded from Poland (complete list in Kornobis \& Peneva (2011)). During a recent survey of the longidorids occurance in Poland, previously unrecorded Longidorus danuvii Barsi, Lamberti and De Luca, 2007 was found. Among normal females of this species, two pathological specimens were found: one bivulval with abnormal structure of the genital tract and one with deformated lip region. Description of morphology and morphometrics of normal and pathological females is presented here.

\section{Matherials and methods}

Soil samples were taken from the rhisosphere of Salix alba L. growing on the bank of Strwiąż river, close to village Krościenko in southern-east Poland (geographical coordinates: $49.47721 \mathrm{~N}, 22.68660 \mathrm{E})$. Specimens were extracted from soli by the sieving and decanting method, heat killed, preserved in TAF and subsequently transferred to glycerine by the Seinhorst method (Seinhorst, 1959). In order to ensure correct morphological identification, specimens from Poland were compared with paratypes kindly provided by Dr. László Barsi from Faculty of Sciences, Department of Biology and Ecology, Novi Sad, Serbia.

\section{Results}

\section{Descriptions}

Female (Table 1, Fig. $1 \mathrm{~A}-\mathrm{C}$ ). Body assuming $\mathrm{C}$ shape, more strongly curved in posterior $1 / 3-1 / 4$ of total length. Lip region moderately expanded, anteriorly flattened, latterally rounded, set off by shallow depression. Cuticule usually smooth, in some specimens very fine transverse striation present along whole body with striae more visible on tail. Cuticule $1.5-2 \mu \mathrm{m}$ thick behind lip region, $2-$ $3 \mu \mathrm{m}$ along body, $4-5 \mu \mathrm{m}$ at dorsal and ventral half of the tail length. Hypodermal chord $5-7 \mu \mathrm{m}$ and $10-15 \mu \mathrm{m}$ thick at base of pharynx and mid-body region, respectively. Amphidial fovea pouch like, distinctly and symmetrically bilobed at posterior end (according to the terminology proposed by Decraemer and Commans (2007)). Nerve ring slightly posterior to the base of odontophore, $169.8 \pm$ $4.35(160-174) \mu \mathrm{m}(\mathrm{n}=11)$ from the anterior end. Muscular pharyngeal bulb $4-5$ times longer than wide, nuclei of the dorsal gland situated at $32.6(29-36) \%(n=4)$ of its length, nuclei of ventrosublateral glands at 53.4 (50$56)$ and $55.6(52-58) \%(\mathrm{n}=8)$. Vagina extending to 55.0 $\pm 5.6(47.6-65.8) \%$ of the corresponding body width. Pars distalis vaginae and pars proximalis vaginae $8-14$ and $10-13 \mu \mathrm{m}$ long, respectively. Anterior and posterior uteri $139.8 \pm 10.9(122-158)$ and $133.0 \pm 15.3(114-$ 162) $\mu \mathrm{m}(\mathrm{n}=11)$ long, respectively. Tail conoid with rounded terminus, elongated, dorsally convex, ventrally slightly to clearly concave. Pair of caudal pores on each side.

Anomalies. Bivulval female (Fig. 1 D - E). Morphometrics: $\mathrm{L}=4.82 \mathrm{~mm} ; \mathrm{a}=126.8 ; \mathrm{b}=14.4 ; \mathrm{c}=109.5 ; \mathrm{c}^{\prime}=$ 
$1.69 ; \mathrm{d}=2.3 ; \mathrm{d}^{\prime}=1.5 ; \mathrm{V} 1=50.4 ; \mathrm{V} 2=58.5 ;$ odontostyle $=92 \mu \mathrm{m}$; odontophore $=59 \mu \mathrm{m}$; anterior end to guiding ring $=27 \mu \mathrm{m}$; tail $=44 \mu \mathrm{m}$; hyaline tip $=10 \mu \mathrm{m}$; body width at: lip region $=12 \mu \mathrm{m}$, guiding ring $=18 \mu$, base of pharynx $=31 \mu \mathrm{m}$; vulva $1=38$, vulva $2=38$, anus $=26$ $\mu \mathrm{m}$; distance from vulval to vulva $2=372 \mu \mathrm{m}$. Pars distalis vaginae $10 \mu \mathrm{m}$ long in both vaginae, pars proximalis vaginae of anterior and posterior vaginae 16 and $11 \mu \mathrm{m}$, respectively. Reproductive system associated with the anterior vulva developed anormally: anterior branch turns back at the level of uteri resulting in three branches of genital tract (two of anterior and one of posterior vagina) present in relatively small (372 $\mu \mathrm{m}$ long) space between two vulvae. More detailed observation of this part of the genital tracts not possible due to the overlap of the elements of all three branches, however both reproductive systems appear unconnected. Poorly developed ovary present at the level of second vagina (Fig. 1E). Posterior branch of reproductive system of the second vagina developed similarly to normal females. Remaining morphology similar to normal females from the same population.

Table 1. Morphometrics of females and juveniles of Longidorus danuvii from Poland. Measurements in $\mu \mathrm{m}$ (except for L) and in the form: mean \pm standard deviation (range). Letter $\mathrm{n}$ below measurements indicates number of specimens measured if different than indicated in first line. If number of measurements is lower than five, standard deviation is not given

\begin{tabular}{|c|c|c|c|c|c|}
\hline Character & Females & $\mathrm{J} 1$ & $\mathrm{~J} 2$ & $\mathrm{~J} 3$ & $\mathrm{~J} 4$ \\
\hline $\mathrm{n}$ & 14 & 5 & 3 & 4 & 7 \\
\hline \multirow[t]{2}{*}{ L (mm) } & $4.52 \pm 0.26$ & $1.03 \pm 0.07$ & 1.51 & 2.09 & $3.12 \pm 0.15$ \\
\hline & $(3.99-4.93)$ & $9.36-1.14$ & $(1.37-1.64)$ & $(1.68-2.67)$ & $(2.94-3.33)$ \\
\hline \multirow[t]{2}{*}{$\mathrm{a}$} & $114.6 \pm 8.32$ & $65.7 \pm 6.79$ & 65.5 & $79.7 \pm 9.92$ & $101.7 \pm 7.13$ \\
\hline & $(95.1-130.0)$ & $58.4-73.5$ & $(63.0-68.2)$ & $(64.6-90.8)$ & $(86.6-107.5)$ \\
\hline \multirow[t]{2}{*}{$\mathrm{b}$} & $12.6 \pm 1.00$ & $4.5 \pm 0.40$ & 5.7 & 6.9 & $9.0 \pm 0.33$ \\
\hline & $(11.0-15.1)$ & $4.1-5.0$ & $(5.1-7.3)$ & $(5.9-8.8)$ & $(8.7-9.6)$ \\
\hline \multirow[t]{2}{*}{ c } & $109.2 \pm 8.47$ & $29.2 \pm 2.95$ & 38.8 & 46.9 & $71.6 \pm 2.29$ \\
\hline & $(90.8-120.2)$ & $24.6-32.6$ & $(31.9-44.3)$ & $(44.2-48.9)$ & $(68.5-74.2)$ \\
\hline \multirow[t]{2}{*}{$c^{\prime}$} & $1.60 \pm 0.12$ & $3.18 \pm 0.33$ & 2.59 & 2.2 & $1.91 \pm 0.08$ \\
\hline & $(1.44-1.84)$ & $2.91-3.61$ & $(2.3-2.9)$ & $(1.9-2.5)$ & $(1.78-2.04)$ \\
\hline \multirow[t]{2}{*}{$\mathrm{d}$} & $2.2 \pm 0.12$ & $2.0 \pm 0.14$ & 2.0 & 2.2 & $2.3 \pm 0.12$ \\
\hline & $(2.1-2.5)$ & $1.8-2.1$ & $(1.9-2.1)$ & $(2.0-2.6)$ & $(2.1-2.5)$ \\
\hline \multirow[t]{2}{*}{ d' } & $1.5 \pm 0.06$ & $1.5 \pm 0.07$ & 1.5 & 1.5 & $1.6 \pm 0.06$ \\
\hline & $(1.4-1.6)$ & $1.4-1.6$ & $(1.4-1.6)$ & $(1.5-1.6)$ & $(1.5-1.7)$ \\
\hline $\mathrm{V} /$ replacement & $49.3 \pm 1.96$ & $64.8 \pm 2.49$ & 74.3 & 86 & $92.0 \pm 1.41$ \\
\hline odontostyle & $(46.5-52.5)$ & $(63-68)$ & $(71-78)$ & $(85-88)$ & $(90-94)$ \\
\hline Odontostyle & $\begin{array}{c}90.8 \pm 2.08 \\
(88-95)\end{array}$ & $\begin{array}{l}57.6 \pm 2.3 \\
(55-60)\end{array}$ & $\begin{array}{c}62.7 \\
(60-68)\end{array}$ & $\begin{array}{c}73.8 \\
(69-76)\end{array}$ & $\begin{array}{c}82.6 \pm 2.44 \\
(80-86)\end{array}$ \\
\hline Odontophore & $\begin{array}{l}56.6 \pm 1.71 \\
(53-60)\end{array}$ & - & - & - & - \\
\hline Total stylet & $\begin{array}{l}147.6 \pm 1.76 \\
(146-151)\end{array}$ & - & - & - & - \\
\hline $\begin{array}{l}\text { Pharyngeal bulb } \\
\text { length }\end{array}$ & $\begin{array}{c}81.8 \pm 3.57 \\
(78-87)\end{array}$ & - & - & - & - \\
\hline $\begin{array}{l}\text { Pharyngeal bulb } \\
\text { width }\end{array}$ & $\begin{array}{l}17.2 \pm 1.25 \\
(15-19)\end{array}$ & - & - & - & - \\
\hline $\begin{array}{l}\text { Anterior end to } \\
\text { guiding ring }\end{array}$ & $\begin{array}{l}26.5 \pm 0.76 \\
(25-28)\end{array}$ & $\begin{array}{c}16.4 \pm 0.55 \\
16-17\end{array}$ & $\begin{array}{c}18.3 \\
(17-19)\end{array}$ & $\begin{array}{c}21.8 \\
(20-26)\end{array}$ & $\begin{array}{l}23.9 \pm 1.07 \\
(23-25)\end{array}$ \\
\hline $\begin{array}{l}\text { Genital } \\
\text { primordorium } \\
\text { length }\end{array}$ & - & $\begin{array}{c}15 \\
n=1\end{array}$ & $\begin{array}{c}23.0 \\
(21-24)\end{array}$ & - & $\begin{array}{l}53.6 \pm 4.7 \\
(48-63)\end{array}$ \\
\hline Tail & $\begin{array}{c}41.6 \pm 2.98 \\
(38-47)\end{array}$ & $\begin{array}{c}35.4 \pm 1.82 \\
(33-38)\end{array}$ & $\begin{array}{c}39.7 \\
(37-43)\end{array}$ & $\begin{array}{c}41.5 \\
(38-44)\end{array}$ & $\begin{array}{c}43.6 \pm 1.81 \\
(41-46)\end{array}$ \\
\hline Hyaline tip & $\begin{array}{l}9.5 \pm 0.66 \\
(8-10)\end{array}$ & $\begin{array}{l}4.6 \pm 0.55 \\
\quad(4-5)\end{array}$ & $\begin{array}{c}5 \\
(5-5)\end{array}$ & $\begin{array}{c}6.5 \\
(5-7)\end{array}$ & $\begin{array}{l}8.5 \pm 1.05 \\
(7-10)\end{array}$ \\
\hline $\begin{array}{l}\text { Body width at: lip } \\
\text { region }\end{array}$ & $\begin{array}{c}12.1 \pm 0.47 \\
(11-13)\end{array}$ & $\begin{array}{l}8.2 \pm 0.45 \\
(8-9)\end{array}$ & $\begin{array}{c}9.0 \\
(9-9)\end{array}$ & $\begin{array}{c}9.8 \\
(9-10)\end{array}$ & $\begin{array}{c}10.4 \pm 0.53 \\
(10-11)\end{array}$ \\
\hline guiding ring & $\begin{array}{c}18.1 \pm 0.27 \\
(18-19)\end{array}$ & $\begin{array}{c}12.4 \pm 0.55 \\
(12-13)\end{array}$ & $\begin{array}{c}13.7 \\
(13-14)\end{array}$ & $\begin{array}{c}15.3 \\
(15-16)\end{array}$ & $\begin{array}{c}16.6 \pm 0.53 \\
(16-17)\end{array}$ \\
\hline base of pharynx & $\begin{array}{c}34.4 \pm 1.16 \\
(32-37)\end{array}$ & $\begin{array}{c}16.4 \pm 0.55 \\
(16-17)\end{array}$ & $\begin{array}{c}21.3 \\
(20-23)\end{array}$ & $\begin{array}{c}24.5 \\
(23-26)\end{array}$ & $\begin{array}{c}28.9 \pm 1.21 \\
(27-31)\end{array}$ \\
\hline $\begin{array}{l}\text { vulva or mid- } \\
\text { body }\end{array}$ & $\begin{array}{c}39.6 \pm 2.79 \\
(36-47)\end{array}$ & $\begin{array}{c}15.8 \pm 2.05 \\
(14-19)\end{array}$ & $\begin{array}{c}23.0 \\
(21-24)\end{array}$ & $\begin{array}{c}25.8 \\
(23-28)\end{array}$ & $\begin{array}{c}30.7 \pm 1.60 \\
(29-34)\end{array}$ \\
\hline Anus & $\begin{array}{c}26.0 \pm 1.30 \\
(24-28)\end{array}$ & $\begin{array}{c}11.2 \pm 0.84 \\
(10-12)\end{array}$ & $\begin{array}{c}15.3 \\
(15-16)\end{array}$ & $\begin{array}{c}19.0 \\
(17-20)\end{array}$ & $\begin{array}{c}22.7 \pm 0.76 \\
(22-24)\end{array}$ \\
\hline
\end{tabular}




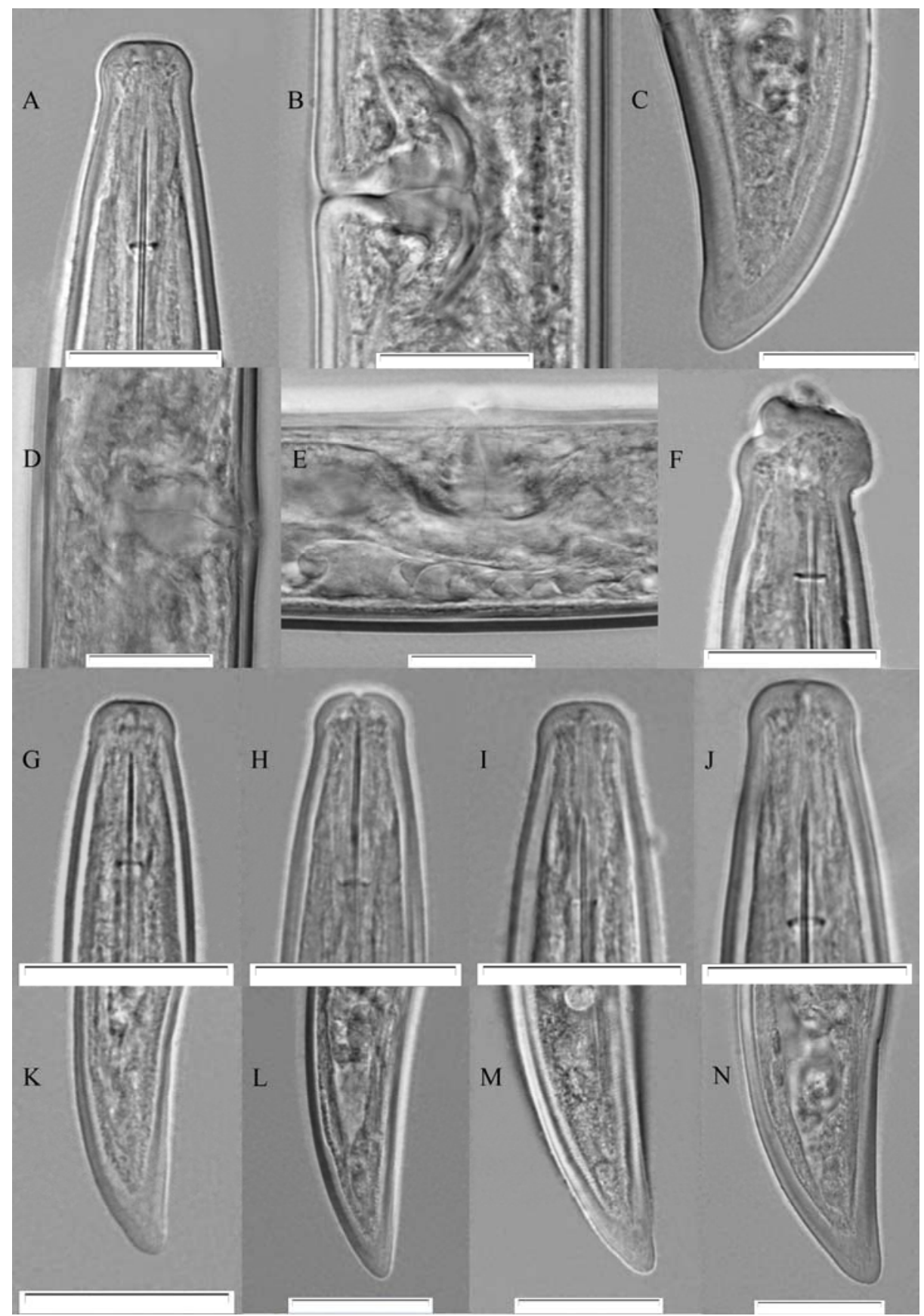

Fig. 1. A. female, anterior end; B. female, vulva; C. female, tail; D. bivulval female, anterior vulva; E. bivulval female, ovary at the level of second vulva; F. female, deformated lip region; G - J. juveniles, J1 - J4 anterior end, respectively; K - N. juveniles, J1-J4 tail, respectively.

Scale bar under each photograph represents $20 \mu \mathrm{m}$.

Female with deformated lip region. One female was found with greatly enlarged and asymetrical lip region (Fig. 1F). Lip region width $16 \mu \mathrm{m}$, remining morphology and morphometrics within range of normal females. This specimen was not included into morphometrics presented in Table 1.

\section{Males. Not found}

Juveniles (Table 1, Figs. $1 \mathrm{G}-\mathrm{N}, 2$ ). Four juvenile stages present. With except of the reproductive system, morphologically similar to adults.

\section{Remarks}

Specimens of $L$. danuvii from Poland are morphologically and morphometrically rather similar to populations from Serbia (Barsi et al. 2007). The main difference in females is shorter tail in population from Poland (41.6 vs 46.4 in type population and 46.5 in additional population associated with Populus sp.) and lower c' value (1.60 vs 1.70 and 1.85).

Data on the morphological and anatomical abnormalities in species of the genus Longidorus are rather scarce, however pathologies of the genital tract similar to those described here were recorded in other species (e.g. in L. euonymus 


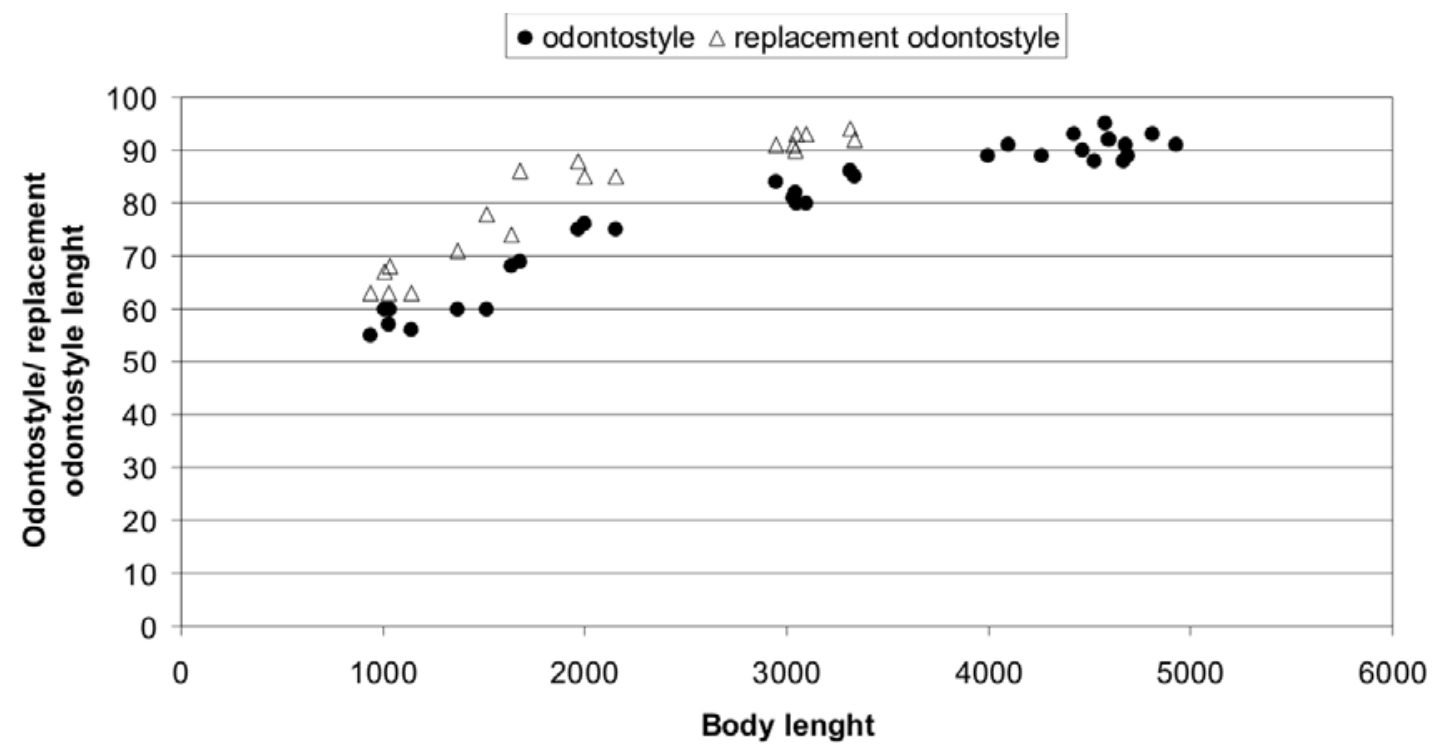

Fig. 2. Scatter plot of the functional and replacement odontostyle in relation to juvenile and females body length in a Longidorus danuvii population from Poland

(Barsi 1994), L. juvenilis (Širca et. al. 2007) and L. poessneckensis (Kornobis \& Peneva 2011)).

To the best of my knowledge, L. danuvii was reported only from two Serbian populations, associated with Amporpha fruticosa L. and Populus sp. (Barsi et al. 2007). The current finding extends geographical and host- associations range known for this species.

\section{Acknowledgements}

This scientific work was financed from means for scientific research in years 2009 - 2012 as a research project. Project number N N303 569238.

\section{References}

BARSI, L. (1994): Bivulval females of Longidorus euonymus, Xiphinema diversicaudatum and X. vuittenezi (Nematoda: Dorylaimida). Nematol. Mediterr., 22, 271 - 271

BARSI, L., LAMBERTI, F., DE LUCA, F. (2007): Morphological and molecular characterisation of Longidorus danuvii sp. n. and L. silvae Roca, 1993 (Nematoda: Dorylaimida) from Serbia. Nematology, 9(4): 585 - 598. DOI: 10.1163/156854107781487279

DeCraemer, W., CoOmans, A. (2007): Revision of some species of the genus Paralongidorus sensu Siddiqi et al. (1993), with a discussion on the relationships within the family Longidoridae (Nematoda: Dorylaimida). Nematology, 9(5): 643 - 662. DOI: 10.1163/156854107782024776

Kornobis, F. W., Peneva, V. (2011): Longidorus poessneckensis Altherr, 1974 and L. piceicola Lišková, Robbins \& Brown, 1997 (Nematoda: Longidoridae): new records from Poland and the first description of the L. poessneckensis male and a bivulval female. Syst. Parasitol., 80 (3): 205 - 216. DOI: 10.1007/s11230-011-9325-8

SEINHORST, J. W. (1959). A rapid method for the transfer of nematodes from fixative to anhydrous glycerin. Nematologica, 4(1): 67 - 69. DOI: 10.1163/187529259X00381

ŠIrcA, S., Stare, B. G., PleŠKo, I. M., Marn, M. V., UREK, G. (2007). First record of Longidorus juvenilis and L. leptocephalus (Nematoda: Dorylaimida) in Slovenia and their morphometrical and ribosomal DNA sequence analysis. Russ. J. Nematol., 15(1): $1-8$ 